\title{
Finite element simulation of piled raft capacity under different loading conditions
}

Fayek Hassona $^{1}$, PhD, Ahmed Mousa ${ }^{2}$, PhD, Beshoy M. Hakeem ${ }^{3}$, PhD, Abdelrahman A. Y. Elsherief ${ }^{4}$

${ }^{1}$ Professor, Civil Engineering Department, Faculty of Engineering - Minia University, Egypt.

Email: \{fhassona@gmail.com\}

${ }^{2}$ Associate Professor,Civil Engineering Department, Faculty of Engineering - Minia University, Egypt.

Email: \{ahmed.meg61@yahoo.com\}

${ }^{3}$ Lecture, Civil Engineering Department, Higher Institute of Engineering and Technology- Minia, Egypt.

Email: \{Civileng_beshoy@yahoo.com\}

${ }^{4}$ Demonstrator, Civil Engineering, Faculty of Engineering - Nahda University, Egypt.

Email: \{A.elsherief@nub.edu.eg\}

\section{ABSTRACT:}

In the general design of piled raft foundations, total loads are assumed to be taken by the pile. The contact pressure between raft and the soil is neglected. This may lead to loading piles with larger loads than they should be which could be reduced by sharing it with soil on which the raft is based. In this study, a trial was made to separate the amount of load carried by piles and that carried by soil. This was achieved by elevating raft one meter above ground surface. 3D finite element program PLAXIS 3D was used to simulate this case. In this paper, the effect of different parameters on carrying capacity of the piled raft were taken into consideration, such as pile spacing, pile diameter and raft thickness. Finally, to introduce an economical design for piled raft foundation, the settlement reduction ratio (SRR) and load sharing ratio of piles $\left(\alpha_{\mathrm{pr}}\right)$ were determined. The numerical results showed that the load carry by soil increases with the increases of pile spacing. In case of elevated piled raft, the load carried by piles was constant, although the pile spacing was increased under the raft thickness and pile diameter are constant. The discussion of results shows that the load carried by soil ranges from 7-14\% of the total load, and maximum settlement at the elevated piled raft was higher than the maximum settlement at piled raft rested on soil with different pile spacing.

Keywords: Piled Raft, Settlement, PLAXIS 3D, Finite element method, load carried by soil

\section{INTRODUCTION:}

The foundation of any structure transmits the total load to the soil. It should be designed to satisfy the strength, usability and constructability requirements. The effective and economical way to

Revised:2 April, 2021, Accepted:28 July, 2021 control a total and differential settlement is considered when using the piled raft concept. In conventional piled raft foundation design concept, the piles are designed to carry the total load, but it is necessary to take into account the effect of soil in load sharing between piles and soil. Several researchers investigated the behavior of piled raft 
analytically, They indicated that, settlement reduction ratio (SRR), load sharing ratio of piles $\left(\alpha_{\mathrm{pr}}\right)$ and maximum settlement of piled raft was influenced by raft position $[1,2]$. According to

$[3,4]$, the SRR and $\alpha_{p r}$ are effected by pile diameter, while Oh, E., et al [5] concluded that the SRR and $\alpha_{\mathrm{pr}}$ are effected by the raft thickness The load sharing ratio of piles(apr) and settlement reduction ratio (SRR) are defined as follows :

$$
\boldsymbol{\alpha}_{\mathrm{pr}}=\frac{\sum \mathbf{P}_{\text {pile }}}{\mathbf{P}_{\text {total }}}
$$

$S R R=\frac{\text { settlement of piled raft foundation }}{\text { settlement of un piled raft foundation }}$

Where $\boldsymbol{\Sigma} \mathbf{P}_{\text {pile }}$ is the sum of loads at pile head, and $\mathrm{P}_{\text {total }}$ is the total applied loads.

In recent years, the concept of the piled raft has been used extensively in the world. An increasing number of structures, especially buildings, have been founded on them [6-9]. Piled rafts are a combined foundation type of raft and piles, usually selected when large settlements are expected, or additional bearing capacity is required. The raft in contact with soil surface directly shares loads from superstructure contact with piles at a certain loadsharing ratio. If the piled raft system did not take the raft part's load carrying capability into account, the design of piled rafts would become conventional and may be uneconomical[10]. In this paper, the three-dimensional finite element method using the PLAXIS 3D program is used to simulate the behavior of piled raft under different loading locations as shown in Fig. (1). In a numerical study, the influence of various diameter, spacing of piles and varying raft thickness were investigated.

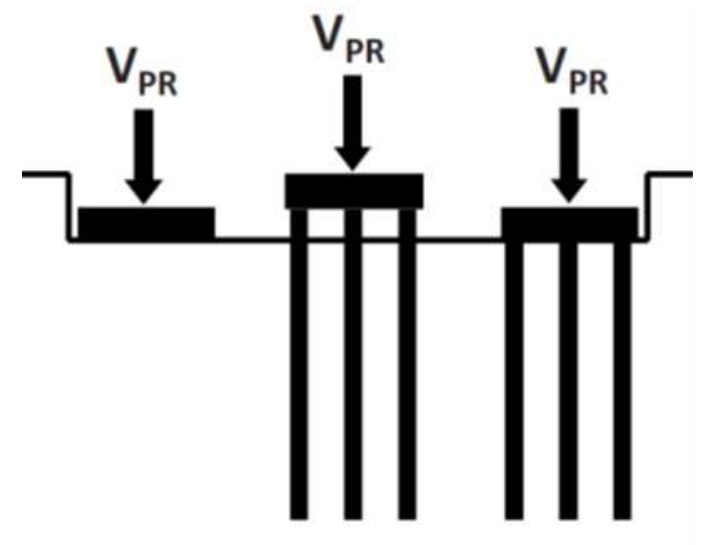

Raft Pile group Piled raft

Figure 1. Representation of total vertical load 'VPR' carried by different foundation systems.

\section{Numerical Model:}

In this study, two systems of piled raft were studied. First, piled raft was elevated above soil by $1 \mathrm{~m}$. Second, piled raft was rested on cohesionless soil. Numerical analyses performed in this investigation were compared with the numerical results reported by Engine 2009 [11] for the verification of used PLAXIS 3D program, then parametric analyses have been carried out to investigate the effect of different parameters on the carrying capacity of piled raft system.

\subsection{Model Verification:}

Prior to performing any numerical analysis, the described simulation procedure was investigated through a comparison with existing research by Engine (2009) [11]. He studied a $130 \mathrm{~m}$ high rise building (Torhaus) located in Frankfurt, which was constructed between 1983 and 1986. Torhaus building consists of two rafts away a part of $10 \mathrm{~m}$ from each other. Two rafts were symmetric with the size $17.5 \mathrm{~m} \times 24.5 \mathrm{~m} \times 2.5 \mathrm{~m}$. Raft bottom was located at $3 \mathrm{~m}$ depth from ground level and constructed on 42 bored pile with 0.9 m diameter 
and $20 \mathrm{~m}$ length for each raft as shown Figure (2). The soil profile consisted of two layers. They were quaternary sand placed at $5.5 \mathrm{~m}$ underground surface, and Frankfurt clay under the quaternary sand. The groundwater level was $3 \mathrm{~m}$ depth from the ground surface, [11]. The building load at each raft was $2 \times 10^{5} \mathrm{KN}$, a uniform load on each raft was $466 \mathrm{KPa}$. Table (1) lists the material used in this verification for modeling the soil using hardening soil model. Embedded pile parameters are given in Table (2). According to Engine (2009) [11] , the unit weight of raft $\gamma=25 \mathrm{KN} / \mathrm{m}^{3}$, the
Young's modulus of raft is equal to $3.7 \times 10^{7} \mathrm{KN} / \mathrm{m}^{3}$ , Poisson ratio of raft $v$. The piles under each raft are arranged as a $6 \times 7$ rectangular configurations with a center-to-center spacing of $2.9 \mathrm{~m}$ and $3.5 \mathrm{~m}$ along the shorter and the larger side of the raft, respectively. According to (Katzenbach et al. 2000), the piled raft foundation's design was based on a traditional method where the piles are assumed to be loaded to their ultimate bearing capacities and raft assumed to transmit the remaining part of the load.
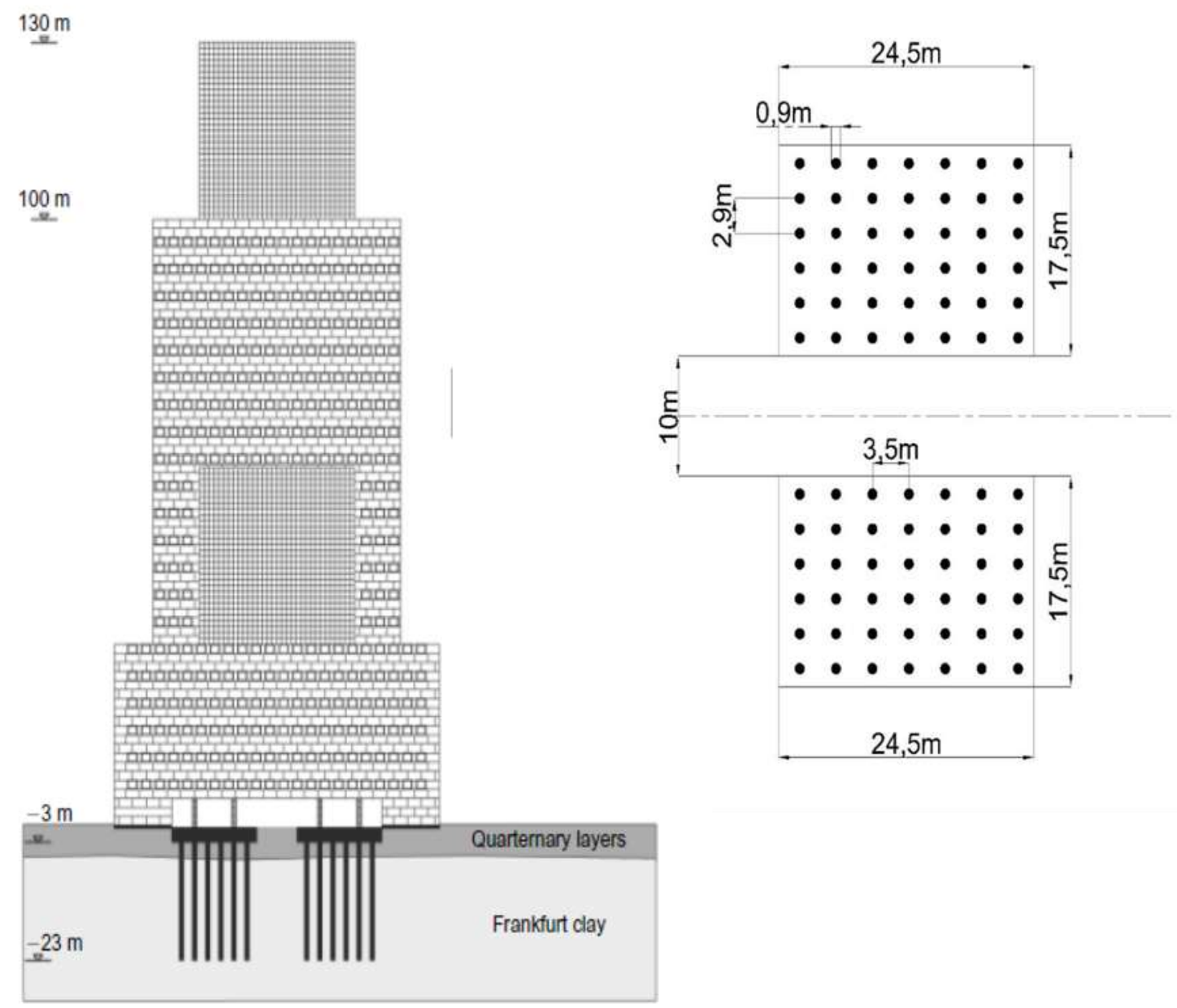

Figure 2. (a) Side view of Torhaus building (b) Top view of the foundation 
Table 1. Model parameter used in the analysis H.K Engine 2009 [11]

\begin{tabular}{|c|c|c|c|}
\hline Property & Unit & $\mathrm{L} 1 * *$ & $\mathrm{~L} 2 * *$ \\
\hline Material model & $\begin{array}{c}\text { Material } \\
\text { model }\end{array}$ & H.S.* & H.S.* \\
\hline Unit weights $\gamma / \gamma_{\text {dry }}$ & $\mathrm{KN} / \mathrm{m}^{3}$ & $11 / 19$ & $10 / 20$ \\
\hline $\begin{array}{l}\text { Reference Secant } \\
\text { stiffness, } E_{50} \text { ref }\end{array}$ & $\mathrm{KN} / \mathrm{m}^{2}$ & $3 \times 10^{4}$ & $3.5 \times 10^{4}$ \\
\hline $\begin{array}{l}\text { Ref. oedometer } \\
\text { stiffness, } E_{\text {oed }}^{\text {ref }}\end{array}$ & $\mathrm{KN} / \mathrm{m}^{2}$ & $3 \times 10^{4}$ & $4.28 \times 10^{4}$ \\
\hline $\begin{array}{l}\text { Ref. unloading-reload. } \\
\text { stiffness, } E_{\text {ur }} \text { ref }\end{array}$ & $\mathrm{KN} / \mathrm{m}^{2}$ & $75 \times 10^{4}$ & $1.05 \times 10^{5}$ \\
\hline $\begin{array}{l}\text { Stress dependency } \\
\text { power, } \mathrm{m}\end{array}$ & - & 0.5 & 1 \\
\hline Poisson's ratio, $v_{L W Y}$ & - & 0.2 & 0.2 \\
\hline Cohesion, $\mathrm{c}^{\prime}$ & $\mathrm{KN} / \mathrm{m}^{2}$ & 0.0001 & 20 \\
\hline Internal friction, $\varphi$ & $\circ$ & 35 & 20 \\
\hline Dilatancy angle, $\Psi$ & $\circ$ & 0 & 0 \\
\hline $\begin{array}{l}\text { At rest lat. Press. coeff. } \\
\text { for } \mathrm{NC}, \mathrm{K}_{\mathrm{o}} \mathrm{NC}\end{array}$ & - & 0.426 & 0.8 \\
\hline $\begin{array}{l}\text { Over consolidation } \\
\text { ratio, OCR }\end{array}$ & - & 1 & 1 \\
\hline $\begin{array}{l}\text { Past overburden press., } \\
\text { POP }\end{array}$ & $\mathrm{KN} / \mathrm{m}^{2}$ & 0 & 0 \\
\hline $\begin{array}{l}\text { Interface stiffness ratio, } \\
\mathrm{R}_{\text {int }}\end{array}$ & - & 1 & 1 \\
\hline \multicolumn{4}{|c|}{$\begin{array}{l}\text { * HS: Hardening Soil Model, } \\
\text { ** L1: Quaternary sand and gravel, } \\
\text { L2: Frankfurt Clay }\end{array}$} \\
\hline
\end{tabular}

Table 2. Embedded pile properties

\begin{tabular}{|c|c|c|}
\hline Property & Unit & Value \\
\hline Pile diameter, D & $\mathrm{m}$ & 0.9 \\
\hline Pile length, L & $\mathrm{m}$ & 20 \\
\hline unit weight, $\gamma$ & $\mathrm{KN} / \mathrm{m}^{3}$ & 15 \\
\hline Moment of inertia, $\mathrm{I}_{2}=\mathrm{I}_{3}$ & $\mathrm{~m}^{4}$ & .032 \\
\hline Poisson's ratio, $v_{\mathrm{ur}}$ & - & 0.2 \\
\hline Young's modu us, E & $\mathrm{KN} / \mathrm{m}^{2}$ & $2.35 \times 10^{7}$ \\
\hline Max. skin friction: & & \\
\hline $\mathrm{T}_{\text {top }} \max$ & $\mathrm{KN} / \mathrm{m}$ & 453 \\
\hline $\mathrm{T}_{\text {bottom }} \max$ & $\mathrm{KN} / \mathrm{m}$ & 453 \\
\hline Max. tip resistance & $\mathrm{KN}$ & 1200 \\
\hline Material type & \multicolumn{2}{|c|}{ Concrete circular pile } \\
\hline
\end{tabular}

Figure (2) shows the results of the FEM and conducted by Engine (2009) and the loadsettlement behavior results obtained by present work analyses is in reasonable agreement with the measured behavior by Engine (2009). The results show agreement between Present and Engine (2009) study with a maximum difference as indicated in Table (3)

The finite element PLAXIS 3D results showed that the piles carry $94 \%$ of total load, whereas the piles carry $92 \%$ of the total load as given by Engine (2009), and this is an agreement to some extent as shown in Table (3).

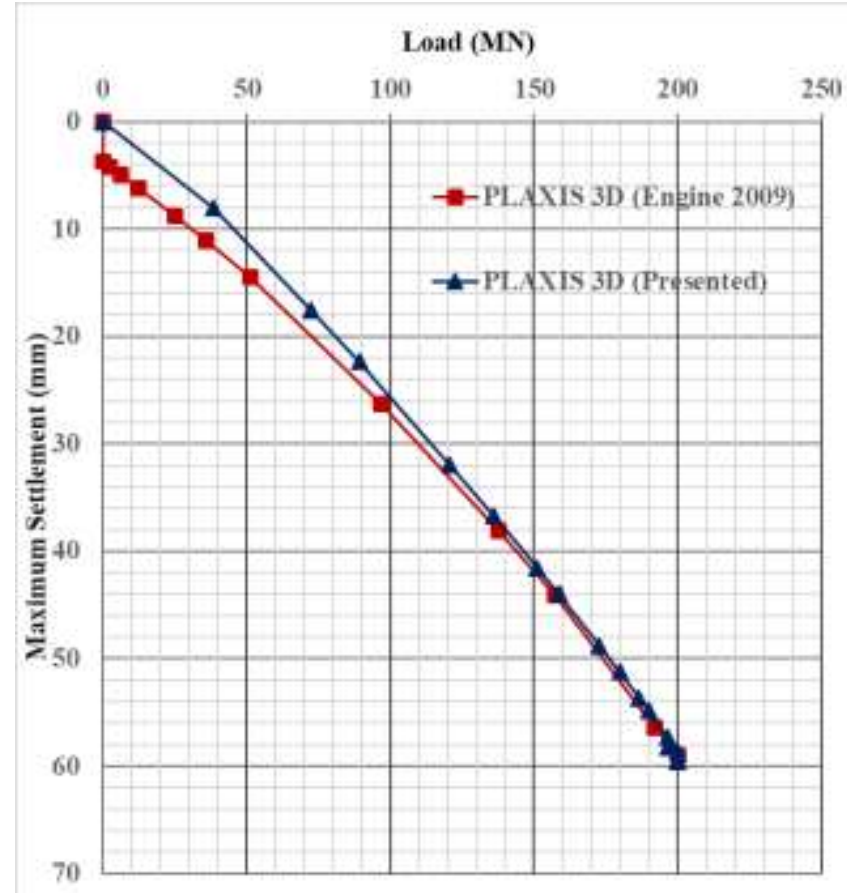

Figure 2. Load settlement of northern piled raft of Messe Torhaus Building

Table 3. Summary of results

\begin{tabular}{|c|c|c|c|c|}
\hline $\begin{array}{c}\text { Name of } \\
\text { Study }\end{array}$ & $\begin{array}{c}\text { Maximum } \\
\text { settlement } \\
(\mathrm{mm})\end{array}$ & $\alpha$ & $\begin{array}{c}\text { Difference } \\
(\mathrm{mm})\end{array}$ & $\%$ Diff \\
\cline { 1 - 2 } Engine 2009 & 60 & $92 \%$ & $1 \mathrm{~mm}$ & $1.6 \%$ \\
\cline { 1 - 3 } $\begin{array}{c}\text { PLAXIS 3D } \\
\text { Presented }\end{array}$ & 59 & $94 \%$ & & \\
\hline
\end{tabular}




\subsection{Finite element simulation:}

As mentioned before, 3-D numerical analysis was performed using 3D Finite element program PLAXIS 3D to simulate the settlement of piled raft under different load conditions. The parametric study's main purpose is to evaluate the load transmission between piles and raft. Also, to investigate the piled raft performance under a variable parameter such as pile spacing, pile diameter, the thickness of raft, and raft location. The following physical properties were adopted in the PLAXIS 3D program.

\subsubsection{Material model parameter:}

\section{Soil properties:}

The soil in all cases was assumed as medium sand according to Egyptian Code of Practice for Soil mechanics and Foundations Design (2001) [12]. The soil properties used in the model are listed in table (4).

\section{Raft properties:}

In this study, three different positions of raft were chosen as shown in Fig (4.a). To simulate the raft in PLAXIS 3D, "plate" is used. All properties of raft used in this study is listed in Table (5).

\section{Pile Properties:}

Modeling a pile in PLAXIS 3D was selected as "Embedded Pile". Resistance of pile in soil depended on the friction resistance only so the value of the tip resistance force equal zero. Table (6) illustrates the pile properties used in the numerical model.

\subsubsection{Modeling Mesh and boundary condition:}

The FE mesh comprised 15-noded wedge is a parametric element and the necessary detailed mesh sensitivity. The lateral boundary of the computational domain allows vertical movement but the boundary sensitivity studied indicated that these should be positioned at a distance of $5 \mathrm{~B}$ according to (Mali 2019) [13].

The model dimension is $(150 \times 150 \times 75 \mathrm{~m})$ carrying a piled raft with dimension $(30 \times 30 \mathrm{~m})$, and the pile length is $20 \mathrm{~m}$ as shown in Fig. (4.b) and Fig. (5). When the geometery model is completed, the finite element mesh can be generated as shown as in Fig (6).

\subsubsection{STUDY RESULTS :}

Thirteen different series of numerical analysis contained thirty one cases were carried out as input parameter such as $\left(D_{\text {pile }}\right),\left(T_{\text {raft }}\right)$ and $\left(S_{\text {pile }}\right)$ were varied to assess their effects on Raft position, and $\left(\alpha_{\mathrm{pr}}\right)$ which are summarized in Table (7). Series 1 and 2 were conducted to investigate the effect piles spacing on raft position to determine load sharing ratio of piles $\left(\alpha_{\mathrm{pr}}\right)$ while $\left(T_{\text {raft }}\right)$ and $\left(D_{\text {pile }}\right)$ were kept constant. Secondly, series 3 of unpiled raft was performed to determine the settlement reduction ratio $(\mathrm{SRR})$ while $\left(T_{\text {raft }}\right)$ was also kept constant. In series 4, 5, 6, 7, 8, 9, 10, 11, 12 and 13, the effects of $\left(D_{\text {pile }}\right),\left(T_{\text {raft }}\right),\left(S_{\text {pile }}\right)$, Pile postion on $(\mathrm{SRR})$ and $\left(\alpha_{\mathrm{pr}}\right)$ were investigated numerically while some parameters were kept constant such as raft dimension and pile length. Table (7) summarized these series. 
Vol.42, No.1. January2023

Table 4. Soil properties used in the numerical model

\begin{tabular}{|c|c|c|c|}
\hline \multicolumn{4}{|c|}{ Parameters of Medium Sand } \\
\hline parameter & Symbol & $\begin{array}{l}\text { Medium } \\
\text { sand }\end{array}$ & unit \\
\hline model & \multicolumn{3}{|c|}{ Hardening model } \\
\hline Drained Behaviour & \multicolumn{3}{|l|}{ Drained } \\
\hline Unsaturated unit weight & $\gamma_{\text {unsat }}$ & 17.00 & $\mathrm{KN} / \mathrm{m}^{2}$ \\
\hline Saturated unit weight & $\gamma_{\text {sat }}$ & 19.00 & $\mathrm{KN} / \mathrm{m}^{2}$ \\
\hline Young's modulus & $E^{\prime}$ & $4 \times 10^{4}$ & $\mathrm{KN} / \mathrm{m}^{3}$ \\
\hline $\begin{array}{l}\text { Secant stiffness in standard } \\
\text { drained triaxial test }\end{array}$ & $\mathrm{E}_{50}^{\mathrm{ref}}$ & $4 \times 10^{4}$ & $\mathrm{KN} / \mathrm{m}^{3}$ \\
\hline $\begin{array}{l}\text { tangent stiffness for primary } \\
\text { oedometer loading }\end{array}$ & $\mathrm{E}_{\mathrm{oed}}^{\text {ref }}$ & $4 \times 10^{4}$ & $\mathrm{KN} / \mathrm{m}^{3}$ \\
\hline $\begin{array}{l}\text { Unloading / reloading } \\
\text { stiffness }\end{array}$ & $\mathrm{E}_{\mathrm{ur}}^{\text {ref }}$ & $12 \times 10^{4}$ & $\mathrm{KN} / \mathrm{m}^{3}$ \\
\hline Cohesion & $S_{\mathrm{u}, \mathrm{ref}}$ & 0.0001 & $\mathrm{KN} / \mathrm{m}^{2}$ \\
\hline angle of internal friction & $\varphi^{\prime}$ & 35.00 & o \\
\hline Angle of dilatancy & $\Psi$ & 5.00 & o \\
\hline $\begin{array}{l}\text { power of stress-level } \\
\text { dependency of stiffness }\end{array}$ & M & 0.500 & \\
\hline Poisson's of ratio & $v_{\text {ur }}^{\prime}$ & 0.300 & \\
\hline $\begin{array}{l}\text { value of normal } \\
\text { consolidation }\end{array}$ & $\mathrm{K}_{\mathrm{o}}^{\mathrm{nc}}$ & 0.426 & \\
\hline Reference stress for stiffness & $P_{\text {ref }}$ & 100 & $\mathrm{KN} / \mathrm{m}^{2}$ \\
\hline Failure ratio & $\mathrm{R}_{\mathrm{f}}$ & 0.900 & \\
\hline initial void ratio & $\mathrm{e}_{\text {init }}$ & 0.500 & \\
\hline
\end{tabular}

Table 5. Raft properties used in the numerical model

\begin{tabular}{|c|c|c|c|}
\hline parameter & Symbol & Values & unit \\
\hline Unit weight & $\gamma$ & 15.5 & $\mathrm{KN} / \mathrm{m}^{2}$ \\
\hline Width & B & 30 & $\mathrm{~m}$ \\
\hline Length & $\mathrm{L}$ & 30 & $\mathrm{~m}$ \\
\hline Thickness & $\mathrm{T}$ & 2 & $\mathrm{~m}$ \\
\hline Young's Modulus & pert & $25 \times 10^{6}$ & $\mathrm{KPa}$ \\
\hline Poisson ratio numerica & model & 0.20 & \\
\hline
\end{tabular}

\begin{tabular}{|l|c|c|c|}
\hline parameter & Symbol & Values & unit \\
\hline Unit weight & $\gamma$ & 6 & $\mathrm{KN} / \mathrm{m}^{2}$ \\
\hline Poisson's ratio & $v_{u r}$ & 0.2 & $\mathrm{Kpa}$ \\
\hline Young's Modulus & $\mathrm{E}$ & $25 \times 10^{6}$ & $\mathrm{~m}$ \\
\hline Lenght & $\mathrm{L}$ & 20 & $\mathrm{~m}$ \\
\hline Diameter & $\mathrm{D}$ & 1 & $\mathrm{KN} / \mathrm{m}$ \\
\hline $\begin{array}{l}\text { Skin friction per } \\
\text { unit length }\end{array}$ & $T_{\text {tob,max }}$ & $\begin{array}{c}\text { Calculated for } \\
\text { each case }\end{array}$ & $\mathrm{KN}$ \\
\hline $\begin{array}{l}\text { Tip resistance } \\
\text { force }\end{array}$ & $F_{\max }$ & $\begin{array}{c}\text { Calculated for } \\
\text { each case }\end{array}$ & Concrete Pile \\
\hline $\begin{array}{l}\text { Material type } \\
\text { Pile type }\end{array}$ & \multicolumn{3}{|c|}{ Massive circular pile } \\
\hline
\end{tabular}

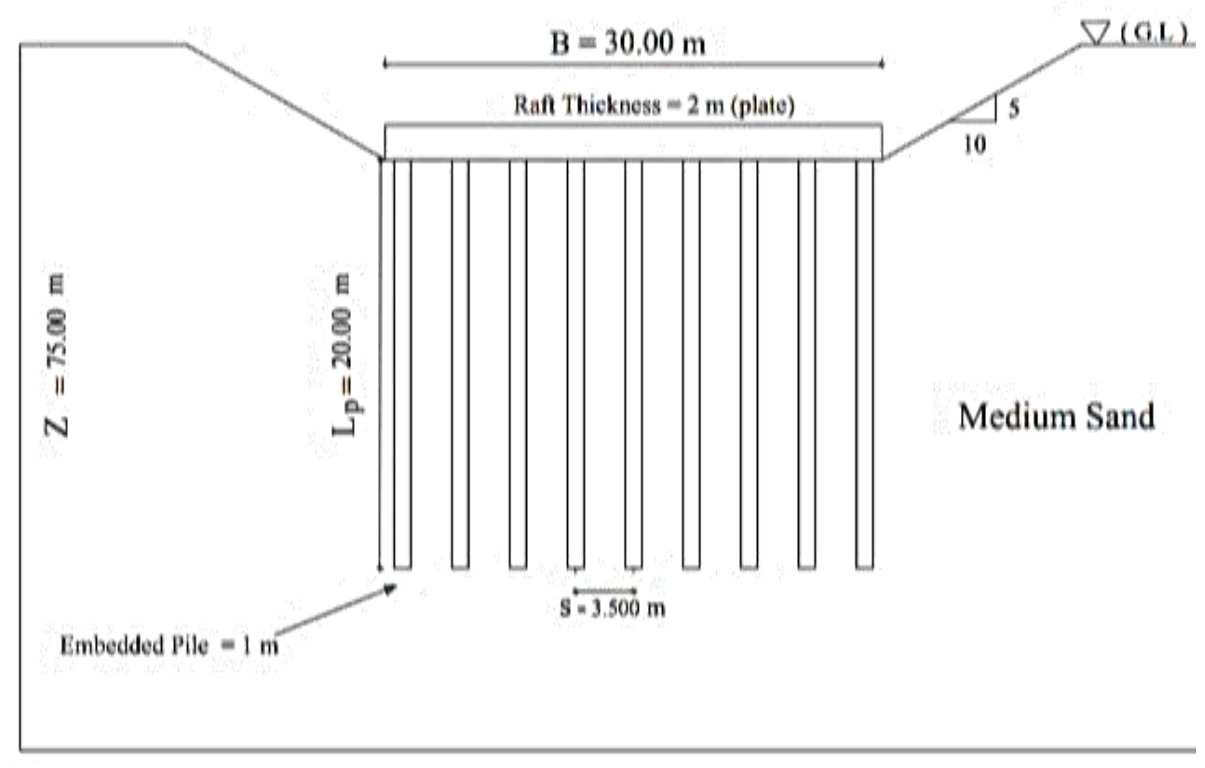

(A)

(B)

Figure 4. (A) Position of raft (B) Geotechnical model 
Piled raft modeled in PLAXIS 3D were composed of square raft dimensions, pile diameter and raft thickness were equal to $30 \times 30 \mathrm{~m}, 1 \mathrm{~m}$ and $2 \mathrm{~m}$, respectively. Number of piles were changed due to change pile spacing while keeping $1 \mathrm{~m}$ distance from center of edge and corner pile to raft edge constant. Four spacing between piles were considered 2.0, 2.8, 3.5 and $4.0 \mathrm{~m}$. The bottom of the raft is located at 5 meters below the ground, the site must be excavated for 5 meters from top to bottom However, 5-meter-deep excavation may be impossible because of stability problems. Therefore, the "Soil body collapses" error may occur during the excavation phase. To overcome this stability problem, the $1 \mathrm{~V}: 2 \mathrm{H}$ approach is applied by excavating the ground angularly.

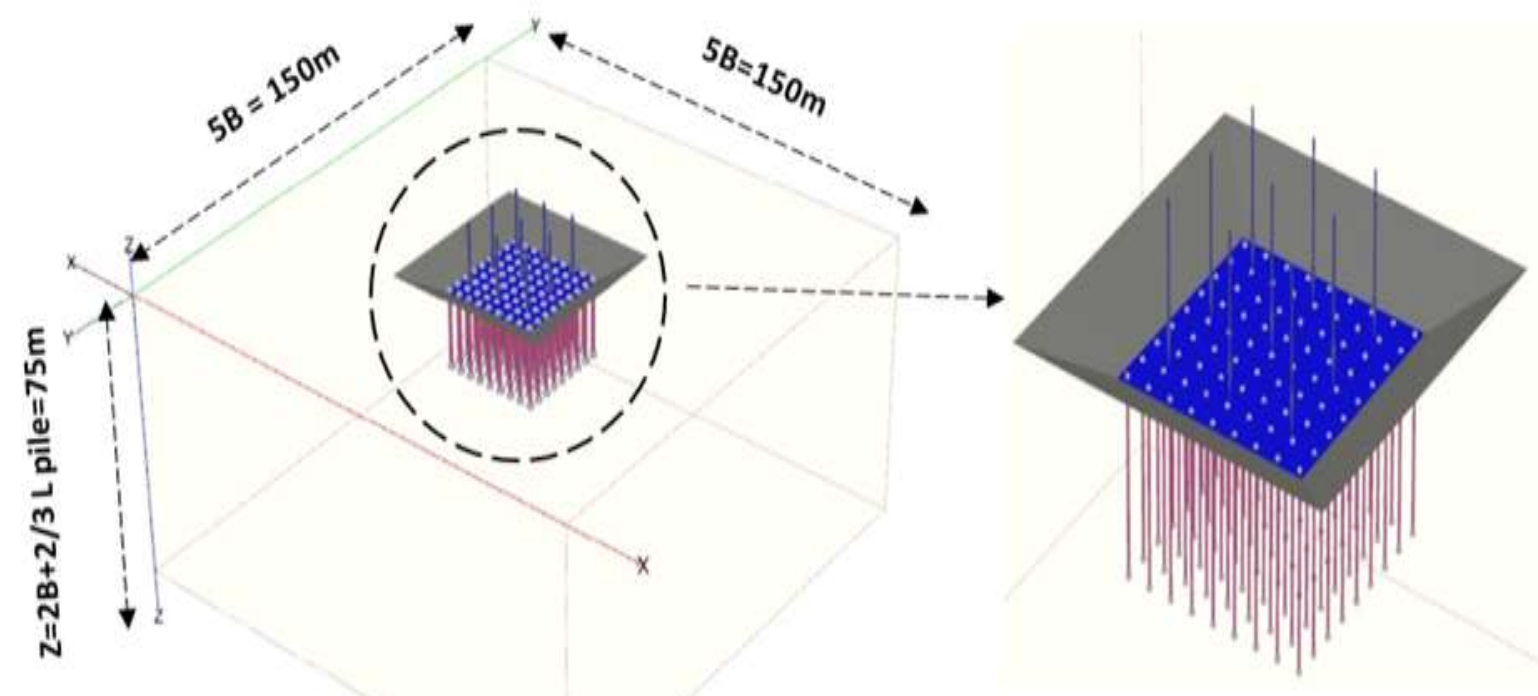

Figure 5. Piled raft model at PLAXIS 3D

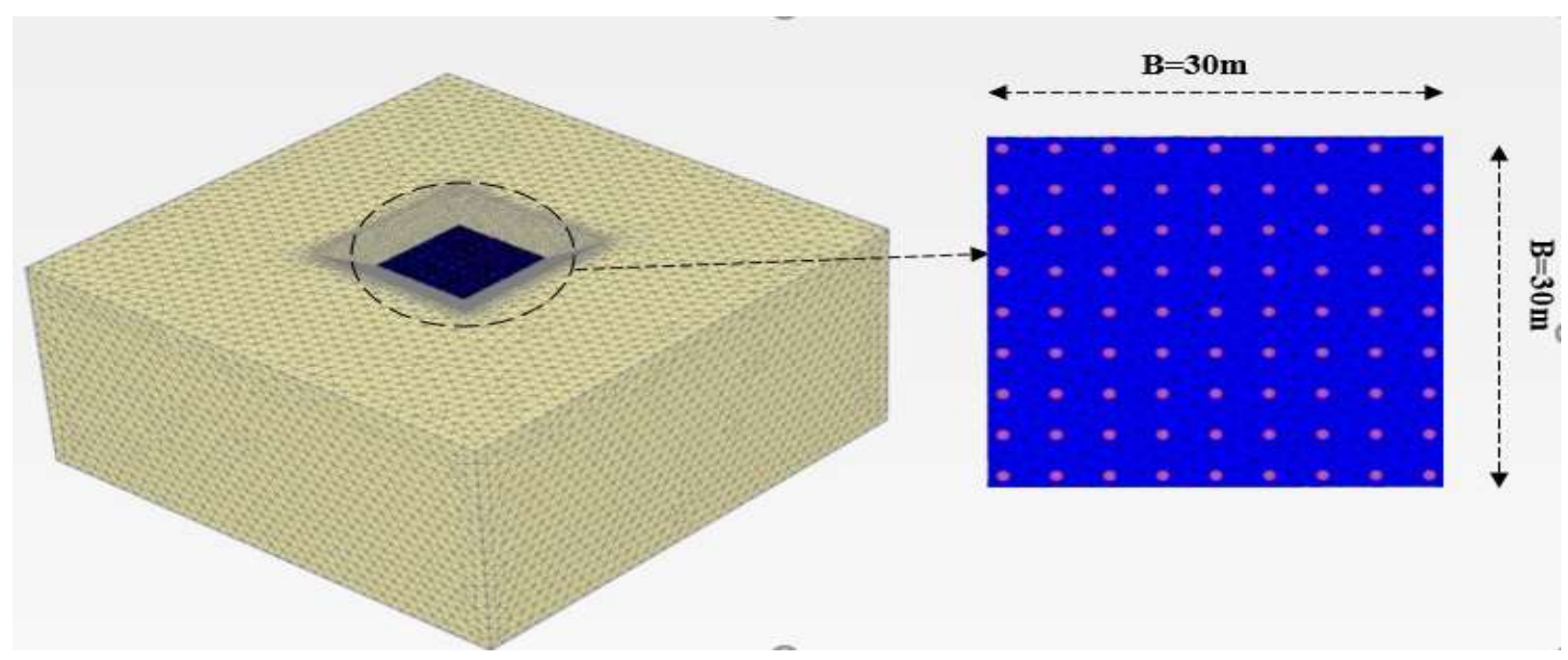

Figure 6. Finite element model for a piled raft 
Vol.42, No.1. January 2023

Table 7. of Numerical analysis program conducted in this study on medium sand

\begin{tabular}{|c|c|c|c|c|}
\hline Series & Raft location & $\begin{array}{c}\text { Pile } \\
\text { diameter }\end{array}$ & $\begin{array}{c}\text { Raft } \\
\text { thickness }\end{array}$ & $\begin{array}{c}\text { Pile } \\
\text { spacing }\end{array}$ \\
\hline 1 & Raft rested on soil & $1 \mathrm{~m}$ & $2 \mathrm{~m}$ & $2,2.8,3.5$ and $4 \mathrm{~m}$ \\
\hline 2 & Raft elevated by $1 \mathrm{~m}$ above soil & $1 \mathrm{~m}$ & $2 \mathrm{~m}$ & $2,2.8,3.5$ and $4 \mathrm{~m}$ \\
\hline 3 & Unpiled raft & - & $2 m$ & - \\
\hline 4 & Raft rested on soil & $1.25 \mathrm{~m}$ & $2 \mathrm{~m}$ & $2,2.8,3.5$ and $4 \mathrm{~m}$ \\
\hline 5 & Raft elevated by $1 \mathrm{~m}$ above soil & $1.25 \mathrm{~m}$ & $2 \mathrm{~m}$ & $3.5 \mathrm{~m}$ \\
\hline 6 & Raft rested on soil & $1.5 \mathrm{~m}$ & $2 \mathrm{~m}$ & $2,2.8,3.5$ and $4 \mathrm{~m}$ \\
\hline 7 & Raft elevated by $1 \mathrm{~m}$ above soil & $1.5 \mathrm{~m}$ & $2 \mathrm{~m}$ & $3.5 \mathrm{~m}$ \\
\hline 8 & Raft rested on soil & $1 \mathrm{~m}$ & $1.5 \mathrm{~m}$ & $2,2.8,3.5$ and $4 \mathrm{~m}$ \\
\hline 9 & Raft elevated by $1 \mathrm{~m}$ above soil & $1 \mathrm{~m}$ & $1.5 \mathrm{~m}$ & $3.5 \mathrm{~m}$ \\
\hline 10 & Unpiled raft & - & $1.5 \mathrm{~m}$ & - \\
\hline 11 & Raft rested on soil & $1 \mathrm{~m}$ & $2.5 \mathrm{~m}$ & $2,2.8,3.5$ and $4 \mathrm{~m}$ \\
\hline 12 & Raft elevated by $1 \mathrm{~m}$ above soil & $1 \mathrm{~m}$ & $2.5 \mathrm{~m}$ & $3.5 \mathrm{~m}$ \\
\hline 13 & Unpiled raft & - & $2.5 \mathrm{~m}$ & - \\
\hline
\end{tabular}

\section{Results and Discussion}

The aim of study is to evalute maximum settlement accompanied with unpiled raft, piled raft rested on soil and piled raft elevated by $1 \mathrm{~m}$ above soil. In addition to calculate load sharing ratio of piles $\left(\alpha_{\mathrm{pr}}\right)$, settlemen reduction ratio (SRR) and load caried by piles and soil under the effect of vaious parameters.

\subsection{Effect of raft location}

Piled raft rested on soil and piled raft elevating by $1.0 \mathrm{~m}$ above soil was analyzed considering the pile spacing $2.00 \mathrm{~m}, 2.8 \mathrm{~m}, 3.5 \mathrm{~m}$, and $4.00 \mathrm{~m}$. The pile length is kept constant at $20 \mathrm{~m}$. The diameter of the pile was set to $1 \mathrm{~m}$ and raft thickness equal $2 \mathrm{~m}$. The uniform load is equal to $300 \mathrm{KPa}$.
A relationship between load and settlement for different pile spacing as shown in Figure (7). It can be seen that maximum settlement of $77 \mathrm{~mm}$, $81.77 \mathrm{~mm}, 87.2 \mathrm{~mm}$ and $93.6 \mathrm{~mm}$ was obtained with pile spacing of $2.0,2.8 \mathrm{~m}, 3.5 \mathrm{~m}$ and $4 \mathrm{~m}$, respectively. When piled raft elevated by $1 \mathrm{~m}$ above soil, the total load transmitted to piles was found to be equal to $315000 \mathrm{KN}$.

Figure (8) shows that maximum settlement of $70.1 \mathrm{~mm}, 72.9 \mathrm{~mm}, 76.8 \mathrm{~mm}$ and $80.3 \mathrm{~mm}$, respectively was obtained with pile spacing of $2.0 \mathrm{~m}, 2.8 \mathrm{~m}, 3.5 \mathrm{~m}$ and $4 \mathrm{~m}$, respectively. when piled raft rested on soil, for case of unpiled raft, the maximum settlement was $150.3 \mathrm{~mm}$. Figure (9) shows a relationship between load carried by piles 
against pile spacing. It was noticed that the total load transmitted to piles was $\left(2.88 \times 10^{5} \mathrm{KN}\right.$, $2.85 \times 10^{5} \mathrm{KN}, \quad 2.79 \times 10^{5} \mathrm{KN}$, and $2.75 \times 10^{5} \mathrm{KN}$ ), respectively with pile spacing of $2.0 \mathrm{~m}, 2.8,3.5 \mathrm{~m}$ and $4 \mathrm{~m}$, respectively, in case of piled raft rested on a soil. Figure (10) shows that SRR values ranged from 0.47 to 0.54 for all used pile spacing.

Figure (11) indicates that pile spacing increased with the loading carried by soil in the.

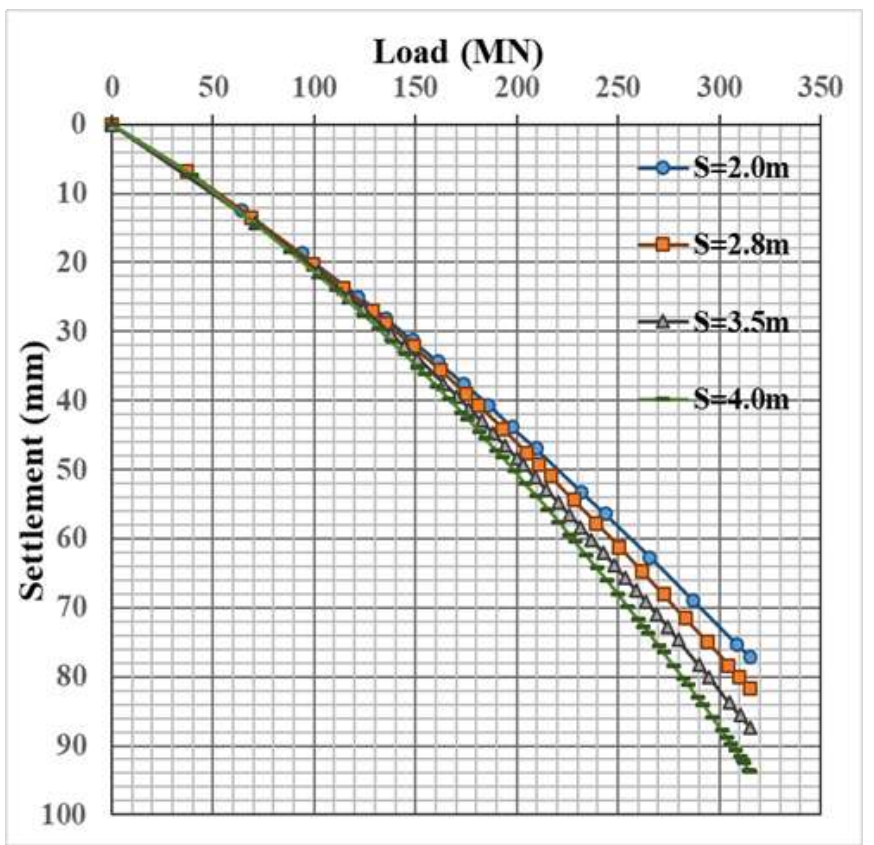

Figure 7. load-settlement curve for piled raft (Raft above soil 1m) piled raft system increased for medium sand soil

Figure (12) explains that load carried by piles in piled raft increased while load carried by the soil in the piled raft system decreased. when pile spacing decreased. The effect of pile spacing on the load-sharing coefficient (apr) as shown in Figure (13). It can be noticed that its value decreases with the increase of pile spacing.

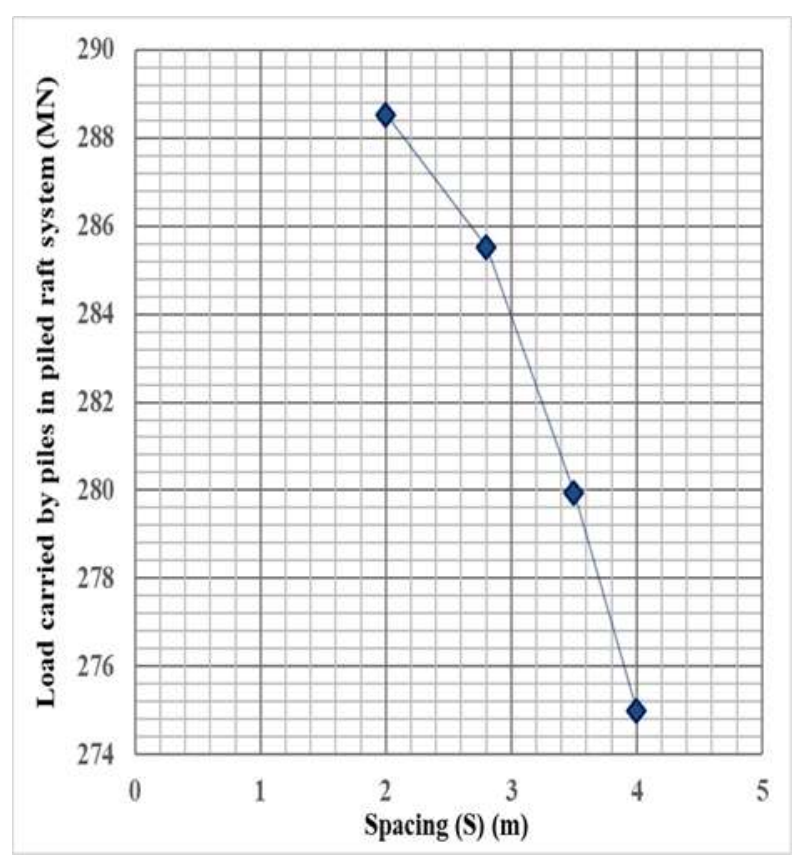

Figure 9. Relation between load carried by piles and the piles spacing (Raft rested on soil ) 
Vol.42, No.1. January2023

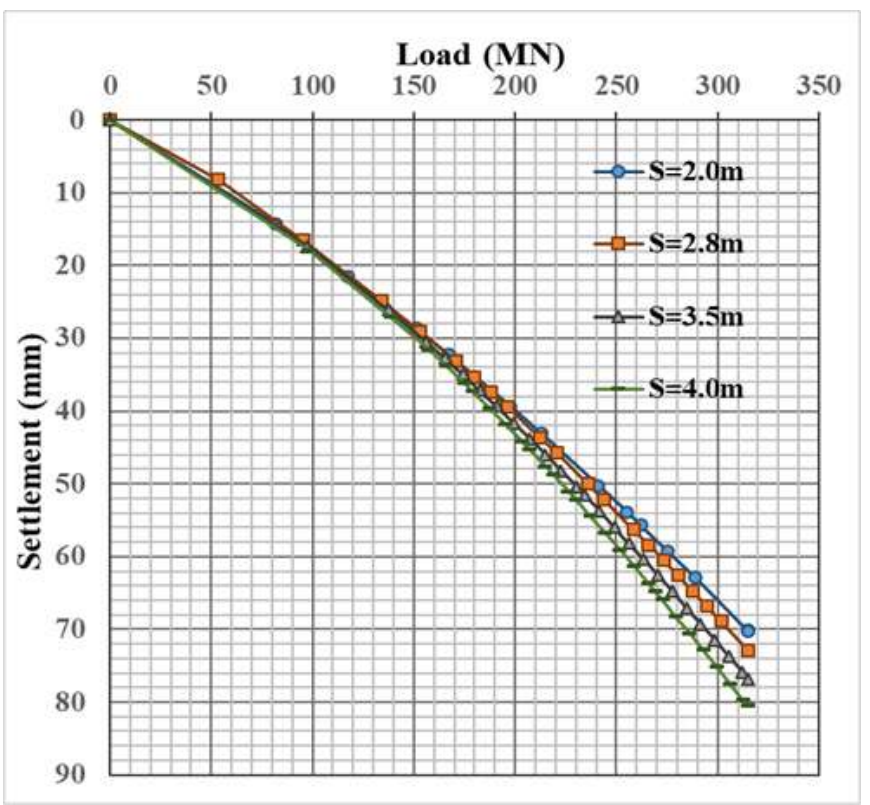

Figure 8. load -settlement curve for piled raft (Raft rested on soil)

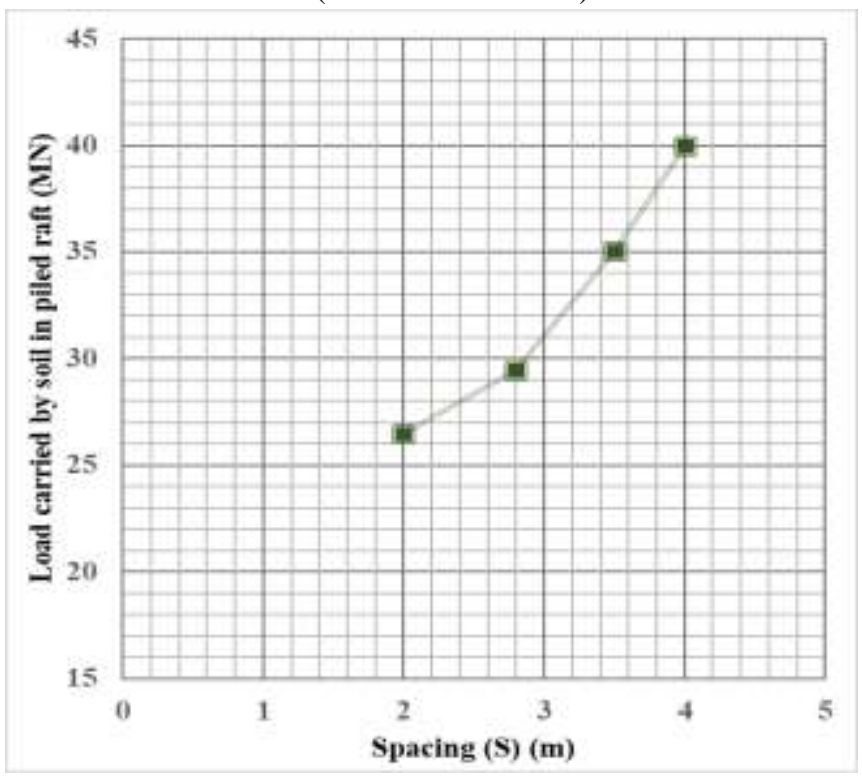

Figure 11. Load carried with soil in a piled raft system VS. spacing between piles $(\mathrm{S})$

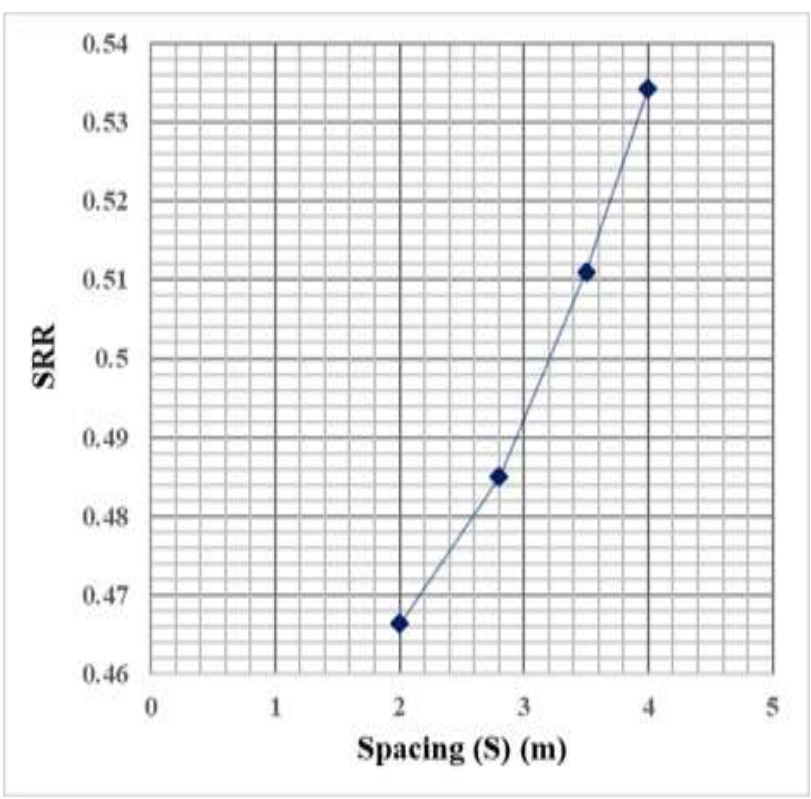

Figure 10. Figure 9. SRR VS Spacing between piles (Raft rested on soil)

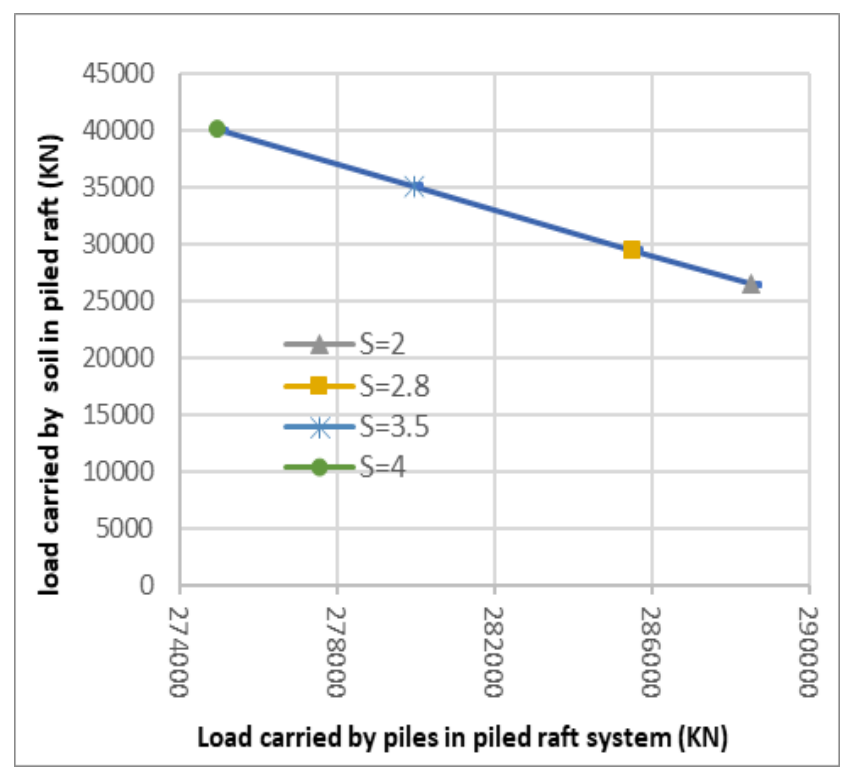

Figure 12. loading carried with soil in the piled raft Vs. Loading carried with piles in the piled raft system 
Vol.42, No.1. January2023

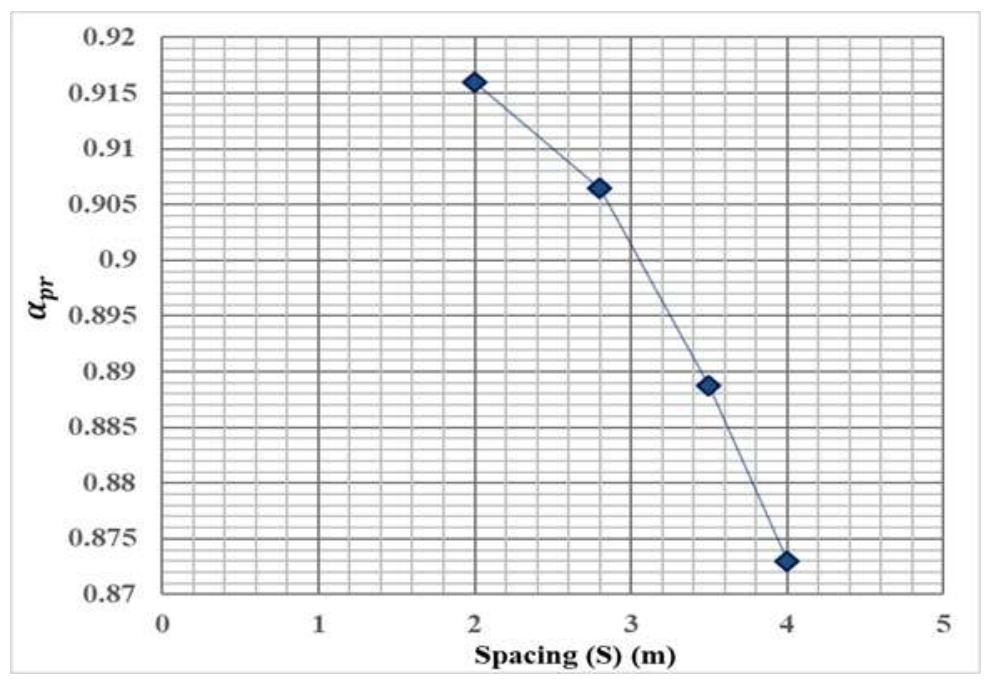

Figure 13. Load sharing coefficient ( $\alpha$ pr) VS spacing(S)

\subsection{Effect of raft thickness}

For piled raft rested on the soil with pile spacing of $2.00 \mathrm{~m}, 2.80 \mathrm{~m}, 3.50 \mathrm{~m}$ and $4.00 \mathrm{~m}$. Various raft thickness equal to $1.5 \mathrm{~m}, 2 \mathrm{~m}$, and $2.5 \mathrm{~m}$ were studied to determine the effect of raft thickness on the settlement of piled raft. Assume the pile length $20 \mathrm{~m}$ and the pile diameter $1 \mathrm{~m}$.

According to Figure (14), it can be noticed that load carried by piles decreases with increasing the pile spacing for different raft thickness rested on soil in all cases. As the thickness of raft increased piles load in a piled raft system increased

due to the increasing in the raft self-weight. Figures (14) and (15) show that the total load carried by soil decreases with increasing of the load carried by piles. Moreover, as pile spacing increased, load carried by soil increased in all cases of raft thickness. On the contrary, as the pile spacing increased, piles load decreased.

The pile load increased in case of elevated piled raft as raft thickness due to the increase in the raft's weight. The piles load for $\left(T_{\text {raft }}\right)$ is $1.5 \mathrm{~m}$, $2.00 \mathrm{~m}$ and $2.50 \mathrm{~m}$ are $303 \times 10^{5} \mathrm{KN}, 3.15 \times 10^{5} \mathrm{KN}$, and $326 \times 10^{5} \mathrm{KN}$. For example, at $3.5 \mathrm{~m}$ spacing, the maximum settlement of piled raft rested on soil (PR) at any raft thickness was less than maximum settlement of elevated pile raft (EPR). The change of maximum settlement is slight for PR at difference raft thickness, as shown at Figure (16). Figure (17) shows that, the value of Settlement reduction ratio is constant for raft thickness $2.0 \mathrm{~m}$ and $2.5 \mathrm{~m}$ with change pile spacing while the value of SRR decreased as pile spacing decreased for raft thickness $1.0 \mathrm{~m}$ 
Vol.42, No.1. January2023

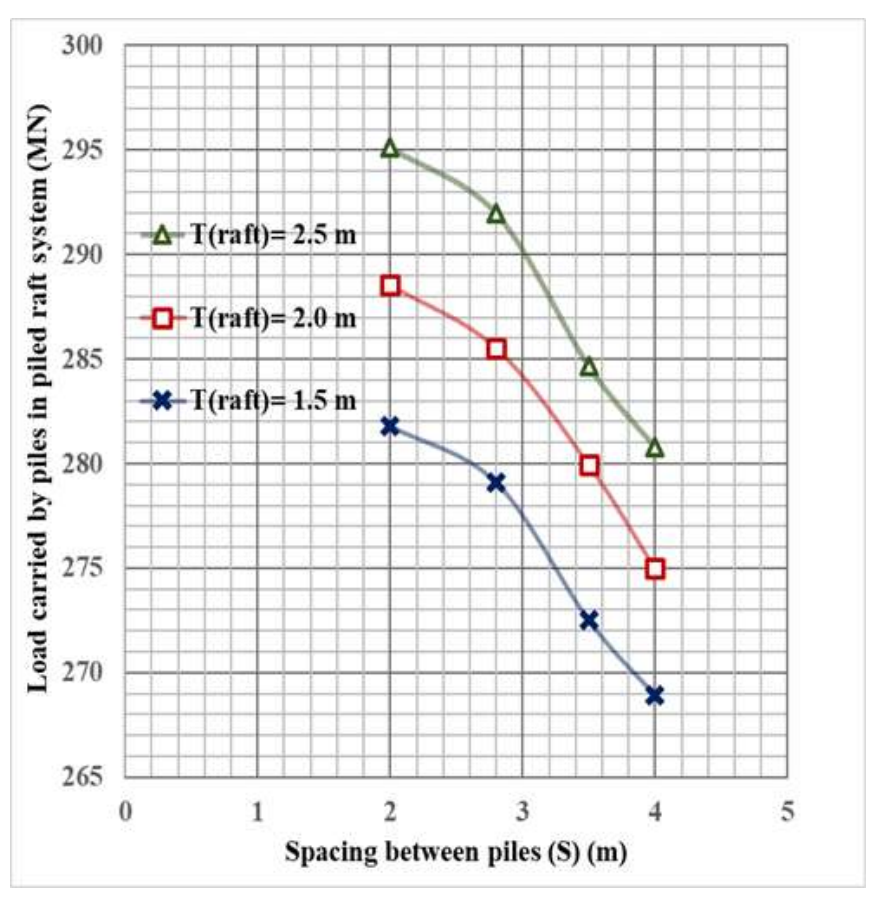

Figure 14. spacing between piles VS. Load carried by piles in a piled raft system

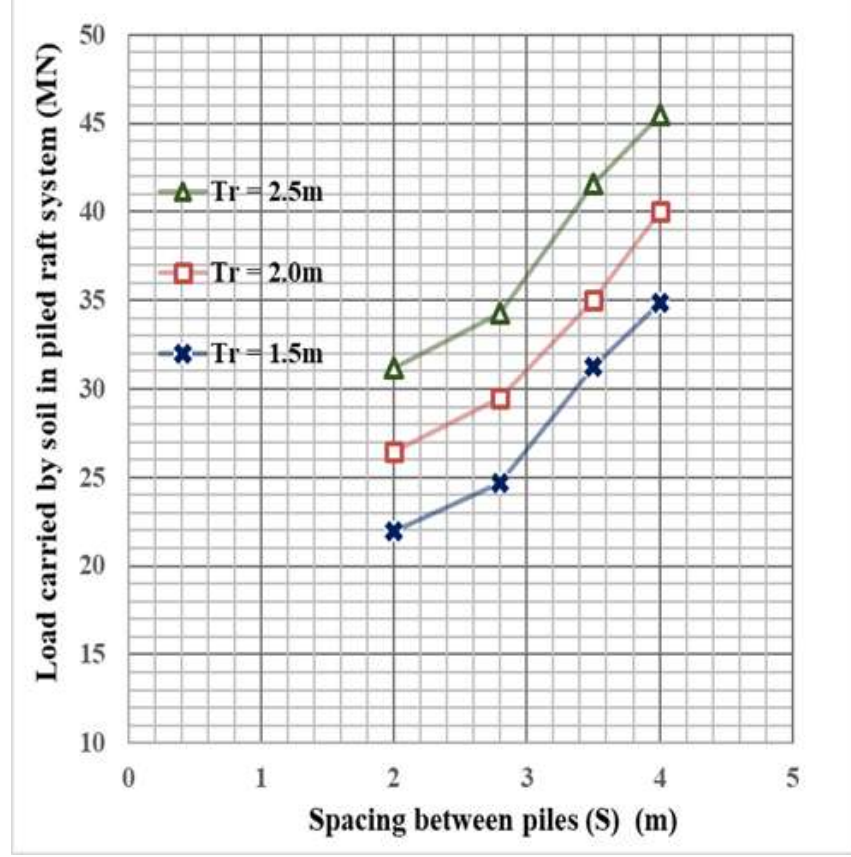

Figure 15: Spacing between piles VS. Load carried by the soil in the piled raft

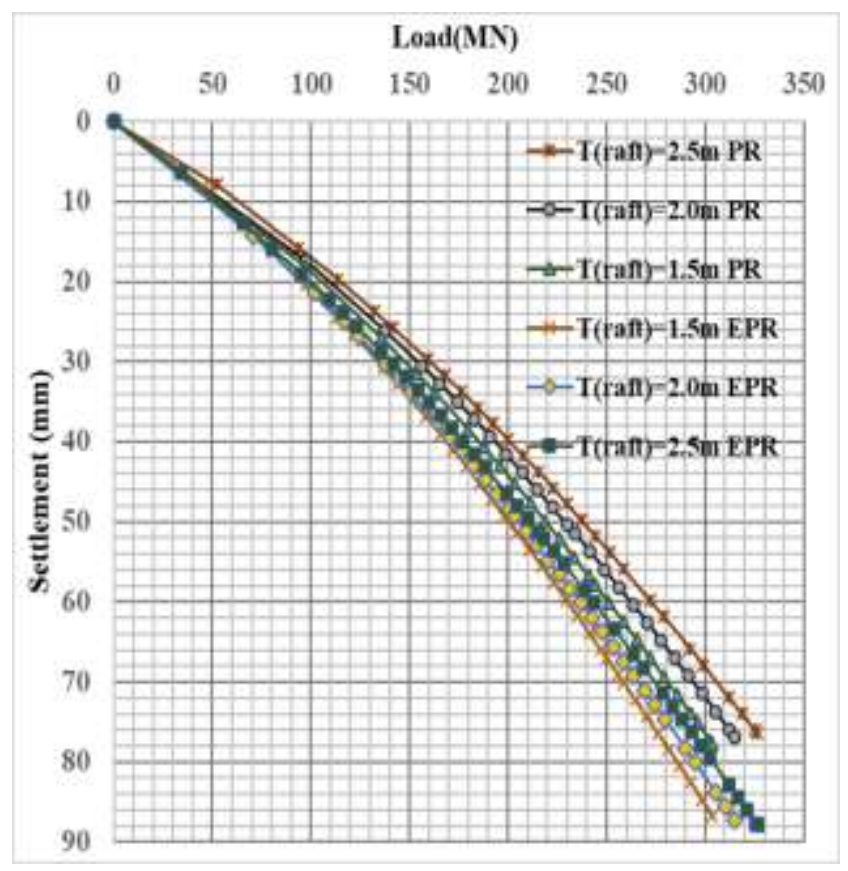

Figure 16. Load -settlement for elevated piled raft at $S=3.5 \mathrm{~m}$ with difference raft thickness

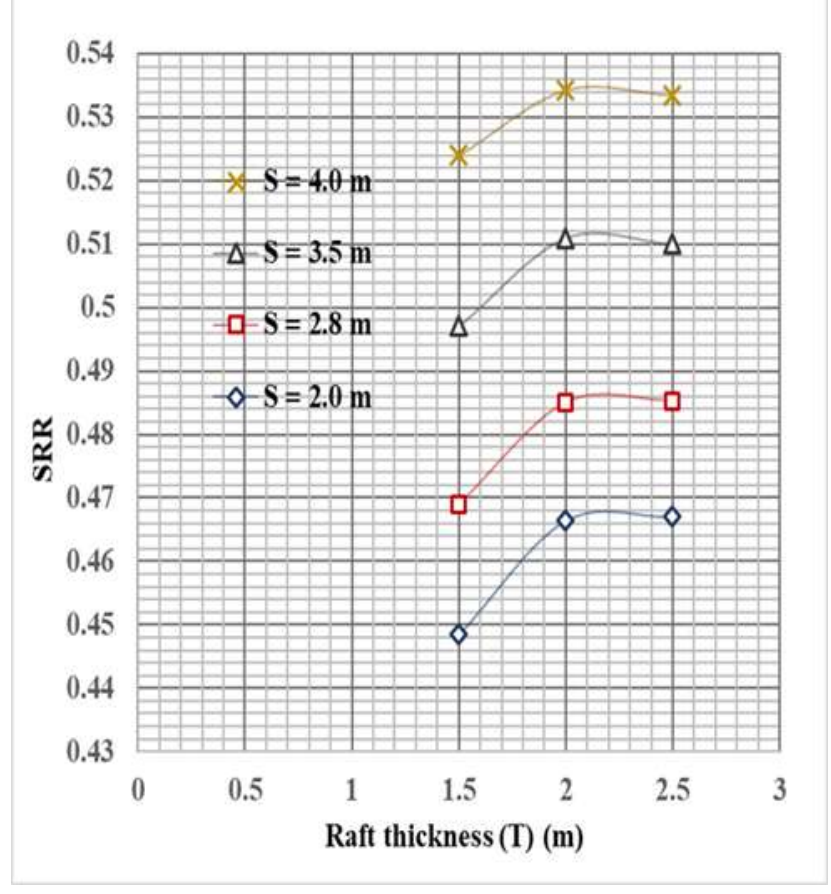

Figure 17. SRR VS. raft thickness 


\subsection{Effect of pile diameter:}

The effect of pile diameter on the settlement of the piled raft rested on soil was studied using pile spacing of $2.00 \mathrm{~m}, 2.8 \mathrm{~m}, 3.5 \mathrm{~m}$ and $4.00 \mathrm{~m}$. Also, the pile diameter was taken from $1.00 \mathrm{~m}, 1.25 \mathrm{~m}$, and $1.5 \mathrm{~m}$ for the raft thickness equal $2 \mathrm{~m}$ and pile length equal $20 \mathrm{~m}$.

For example, at spacing $4.0 \mathrm{~m}$, settlement reduction ratio decreased as pile diameter increased. At diameter 1.0m, SRR decreased as pile spacing decreased, as shown at Figure (18). According to Figure (19), as pile diameter decreases, the soil load in a piled raft system

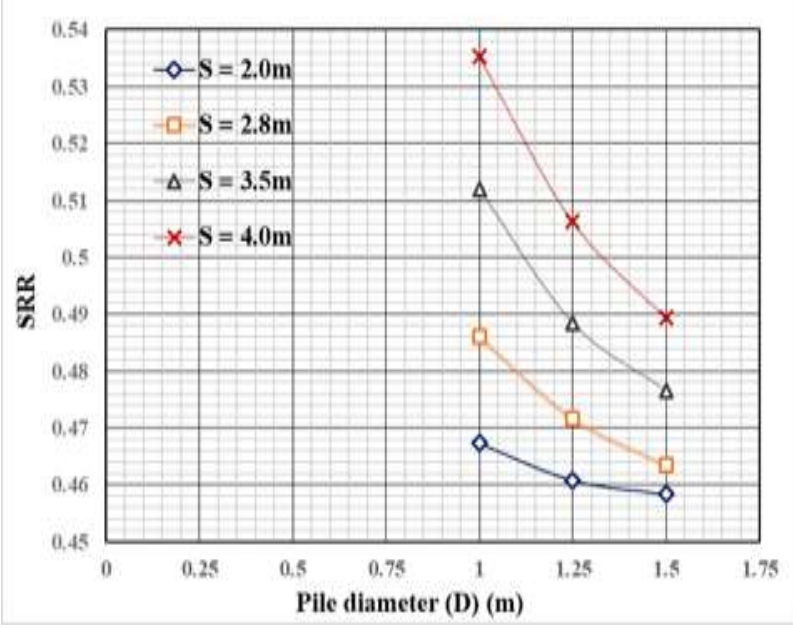

Figure 18. SRR VS. pile diameter

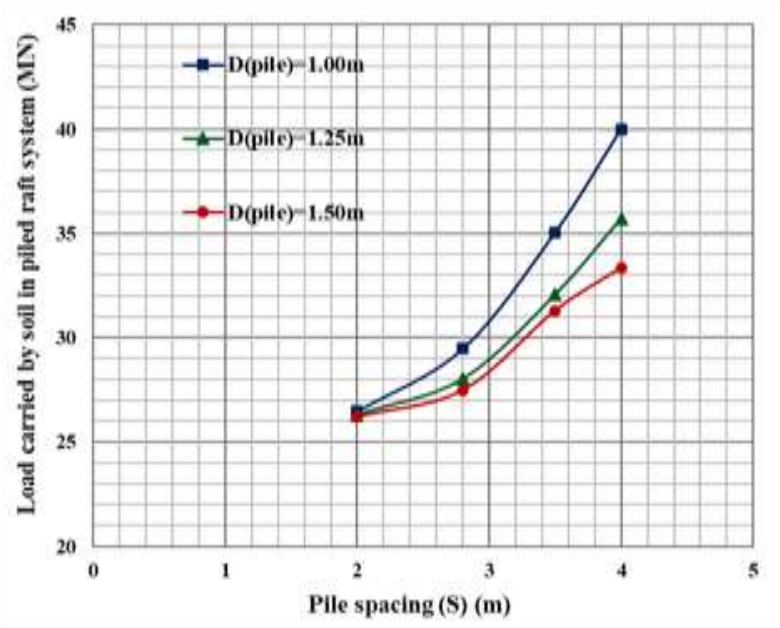

Figure 19. loading carried by the soil in a piled raft system VS.153 spacing between piles (S) increases with different pile spacing. As pile spacing increases, the load carried by soil increases. According to Figure (20), as pile diameter increases, pile load increases with the different pile spacing. Also, as pile spacing between piles increases, the soil's load in the piled raft system increases for raft thickness.

In Fig (21), it could be observed that, for spacing $3.5 \mathrm{~m}$, the maximum settlement of piled raft rested on soil (PR) is less than a maximum settlement of elevated piled raft (EPR). On the other hand, as the pile diameter increases, the maximum settlement decreases whether in PR or EPR.

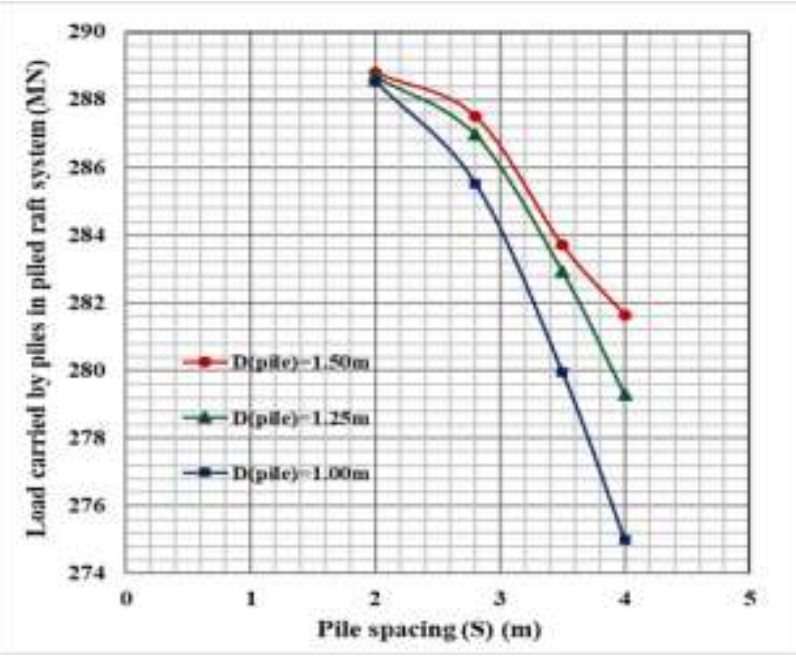

Figure 20: Spacing between piles VS.load carried by the piles in the piled raft

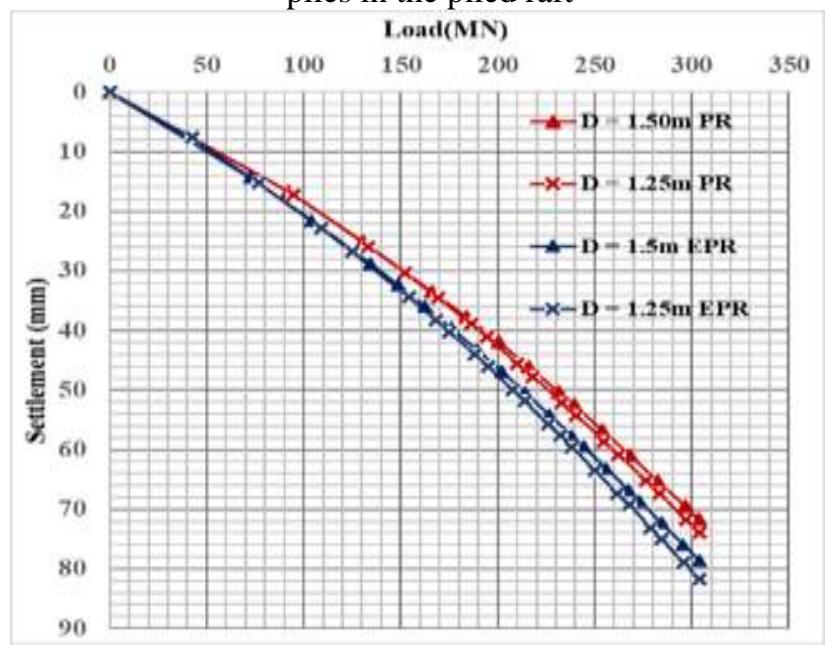

Figure 21. Load -settlement for elevated piled raft and piled raft at $S=3.5 \mathrm{~m}$ with a difference pile diameter 


\section{Conclusion:}

Based on the current study, it could be concluded that:

1. The results obtained from finite element analyses using PLAXIS 3D with Hardening Soil Model (HSM) have a good agreement with load-settlement behavior of piled raft system results presented by Engine (2009).

2. The maximum settlement at elevated piled raft $1 \mathrm{~m}$ above soil was higher as compared to piled raft settlement rested on soil in all analyzed pile spacing.

3. In case of elevated piled raft, the load carried by piles was constant although the pile spacing was increased due to the absence of contact between soil and raft. However, the load of single pile load, within grouped piles, increased, as the pile spacing increased.

4. Load carried by soil at piled raft system increased as the spacing between piles increased and load carried by piles decreased.

5. The load carried ratio by soil ranged from 7 $14 \%$. Whereas the greater the distance between piles, the greater is this ratio. According to the previous domain, load carried by soil increased with the increase of raft thickness and decrease of pile diameter.

6. The settlement reduction ratio ranges between $0.45-0.54$, which increases with the increase in pile spacing, and therefore, the settlement reduction ratio decreased as piles diameter increased and pile spacing decreased.

7. Both piles load and load sharing ratio of piles increased as pile spacing decreased and pile diameter increased. Also, both piles load and load sharing ratio of piles increase with increasing of raft thickness.

\section{REFERENCES:}

1. Deb, P. and S.K. Pal, Analysis of Load Sharing Response and Prediction of Interaction Behaviour in Piled Raft Foundation. Arabian Journal for Science and Engineering, 2019. 44(10): p. 8527-8543.
2. Watcharasawe, K., P. Kitiyodom, and P.J.S.E.A.G.S.J. Jongpradist, Numerical Analyses of Piled Raft Foundation in soft soil using 3D-FEM. 2015. 46(1): p. 109-116.

3. Prakoso, W.A., F.H.J.J.o.G. Kulhawy, and G. Engineering, Contribution to piled raft foundation design. 2001. 127(1): p. 17-24.

4. Oh, E., et al., Numerical analysis of piled raft foundation in sandy and clayey soils. 2009. 6(6).

5. Oh, E., et al. Finite element modelling for piled raft foundation in sand. in Eleventh East AsiaPacific Conference on Structural Engineering \& Construction (EASEC-11)“Building a Sustainable Environment", Taipei, Taiwan. 2008.

6. Cooke, R.J.G., Piled raft foundations on stiff clays-a contribution to design philosophy. 1986. 36(2): p. 169-203.

7. Katzenbach, R., U. Arslan, and C.J.D.a.o.r.f. Moormann, 13. Piled raft foundation projects in Germany. 2000: p. 323.

8. Reul, O. and M.J.G. Randolph, Piled rafts in overconsolidated clay: comparison of in situ measurements and numerical analyses. 2003. 53(3): p. 301-315.

9. Comodromos, E.M., M.C. Papadopoulou, and L.J.C.G.J. Laloui, Contribution to the design methodologies of piled raft foundations under combined loadings. 2016. 53(4): p. 559-577.

10. Vakili, R., Load sharing mechanism of piled-raft foundation in sand. 2015, Concordia University.

11. Engin, H. and R. Brinkgreve. Investigation of pile behavior using embedded piles. in Proceedings of the 17th International Conference on Soil Mechanics and Geotechnical Engineering. 2009.

12. Code, E., Soil mechanics, design and construction foundation. 2001, Part. 
Vol.42, No.1. January2023

\section{NOTATION:}

$\begin{array}{ll}\boldsymbol{\alpha}_{\mathbf{p r}} & \text { Load sharing ratio } \\ \text { of piles }\end{array}$

SRR

Settlement

reduction ratio

PR

Piled raft rested

on soil

EPR Elevated piled raft

$\boldsymbol{T}_{\text {raft }} \quad$ Raft thickness

$\boldsymbol{D}_{\text {pile }}$ Pile diameter

$S_{\text {pile }} \quad$ Pile Spacing 